\title{
2. Evolution of national systems of labour administration since the adoption of the ILO Labour Administration Convention, 1978 (No. 150)
}

\author{
José Luis Daza
}

\subsection{INTRODUCTION}

While labour legislation and social policies and programmes have received considerable attention from researchers, few studies have sought to analyse the development of labour administrations over time. ${ }^{1}$ This chapter adds to knowledge in this regard by describing and evaluating challenges associated with the evolution of national systems of labour administration, focusing on the period since the 1970s, the decade in which the International Labour Organization's (ILO) Labour Administration Convention, 1978 (No. 150) was adopted. In so doing, the chapter draws on a variety of sources, in particular documents produced by the ILO.

The evolution of labour administrations since the 1970s can be analysed in terms of distinctive periods that can be distinguished from each other by significant events. This chapter divides the development of labour administration into five periods: firstly, labour administrations at the time of the adoption of Convention No. 150 (the 1970s); secondly, the 1980s (from the adoption of Convention 150 to the fall of the Berlin Wall and the dissolution of the Soviet Union); thirdly, the 1990s (the end of a 'bipolar world' and advance of globalization; fourthly, the twenty-first century (from the beginning of the new century to the financial and economic crisis of 2008); and finally, the post-crisis era (or the period between the financial crisis and the COVID-19 crisis). The chapter shows how changes in the organization of labour administration are related to wider developments in the economy and society and also examines the implications for the role of the State and social partners. 


\subsection{LABOUR ADMINISTRATIONS AT THE TIME OF ADOPTION OF CONVENTION NO. 150 (THE 1970S)}

Although ILO Convention No. 150 was adopted in 1978, public administration in the field of national labour policy has existed since the last decades of the ninetieth century. By the beginning of the twentieth century a number of countries had developed services for the framing, application and enforcement of labour legislation. However, it was only after the First World War that ministries dealing exclusively with labour and social questions became common. During the inter-war period, ministries that had started with regulations relating to labour began to assume a range of competencies on employment, social insurance and safety at work. The generalization of systems of collective bargaining was accompanied by the development of conciliation, mediation and arbitration procedures and machinery. The economic depression of the 1930s and the subsequent Second World War also had repercussions for the development of social security administration, employment services and unemployment benefits (Wallin, 1969). ${ }^{2}$ After the war, several ILO conferences and meetings of experts discussed different aspects of labour administration. The essential functions of the system of labour administration concerning specific matters were dealt with in important international labour conventions, including the Labour Inspection Convention, 1947 (No. 81), the Labour Inspection (Agriculture) Convention, 1969 (No. 129), the Employment Service Convention, 1948 (No. 88), the Employment Policy Convention, 1964 (No. 122), and Human Resources Development Convention, 1975 (No. 142).

During the 1970s, the economic shock that followed the oil crisis of 1973 meant that 'action against unemployment became the first priority of labour administration in most industrialized countries' (ILO, 1989). However, the context in which ILO Convention No. 150 and Recommendation No. 158 were discussed and adopted in the late 1970s was also one that involved political and economic blocks (industrialized market economy countries, socialist countries with a planned economy, developing and non-aligned countries) with different characteristics. In a context of high unionization, the management of labour relations continued to be one of the primary functions of systems of labour administration. Employment policies and the enlargement of social security were national policy objectives.

Labour Administration Convention No. 150 and its accompanying Recommendation No. 158, were adopted by the ILO in 1978 in order to consolidate existing labour administration practice in international standards and establish fundamental principles to be followed by national governments. Both instruments provide general guidelines to ensure the organization 
and effective operation of a national system of labour administration with functions and responsibilities properly coordinated. They allow a variety of approaches to be adopted that can take appropriate account of different and changing national circumstances (ILO, 1997). The approved instruments define labour administration as 'public administration activities in the field of national labour policy'. The term 'system of labour administration' covers all public administration bodies responsible for and/or engaged in labour administration - whether they are ministerial departments or public agencies, including parastatal and regional or local agencies or any other form of decentralized administration - and any institutional framework for the coordination of the activities of such bodies and for consultation with and participation by employers and workers and their organizations. The instruments emphasize the importance of a prominent role for social partners in labour administration. Governments shall make arrangements appropriate to national conditions to secure, within the system of labour administration, consultation, cooperation and negotiation between the public authorities and the most representative organizations of employers and workers, or - where appropriate - employers' and workers' representatives. In accordance with national laws or regulations, or national practice, governments can delegate or entrust certain activities of labour administration to employers' and workers' organizations.

The notion of national labour policy, as a generic flexible concept, includes the preparation of legislation, support for the industrial relations system, the development of adequate working conditions, the promotion of employment and research in labour matters. Those aspects are developed in ILO Recommendation No. 158. Labour inspection and employment services were presumed to be among the key administrative services. In many countries, vocational training for employment as well as social security were considered part of the national policy on work and, as such, also part of the labour administration.

\subsection{THE $1980 \mathrm{~S}$}

Following considerable changes in the world economy in the 1980s, the International Labour Office decided to examine the current state of labour administration, recognizing that the economic and social context of labour administration had altered in the decade since the approval of Convention No. 150. As the resulting study Labour administration in a changing world (ILO, 1989), emphasized:

The economic crisis that began in the early 1970s and the changes associated with it constituted the predominant forces that determined labour policy and had posed a formidable challenge to labour administration for almost two decade ... During 
the 1980s, the policies of particular national governments and policy packages imposed by the International Monetary Fund and the World Bank led to a change in attitudes to the role of the public sector, and this significantly changed the environment in which labour administrations operated ... in the developing countries, austerity measures and 'adjustment plans' resulted in the contraction of the public sector, with labour administration being substantially affected in terms of budget and staff cuts. (ILO, 1989: 8, 25, 9)

Industrialized countries had adopted a wide range of active and passive measures to deal with mounting unemployment (ILO, 1989: 19). In socialist countries, the focus of ministries of labour was the provision of a comprehensive social insurance and unilateral regulation of working conditions (in the absence of free and independent employers and workers' organizations) through labour laws. As unemployment was considered frictional in these countries, the main employment-related task of labour administration was to organize and regulate labour flows. Efforts also were made to make administrative services, and especially the management of pension institutions, more efficient: "most of the socialist countries were in the process of equipping their labour administrations, strengthening their social security services with the introduction of computerization' (ILO, 1989: 13).

Decentralization of responsibility for some aspects of labour administration became a growing trend in many industrialized countries, although not in developing countries. Another important trend was associated with efforts to improve performance and efficiency through the introduction of new techniques and technologies and improved management of resources (ILO, 1989: 43). However, labour administrations in most countries during the 1980s experienced difficulties in attracting and retaining well-qualified staff because salaries, conditions and career prospects tended to be inferior to the private sector and, in some cases, to those offered by other ministries or public bodies. Developing countries experienced additional problems such as a lack of transportation for officials combined with a failure to adequately reimburse their travel, particularly those of labour inspectors. Other difficulties included a lack of laboratory facilities, testing equipment, office material, stationery and documentation, poor resource management, and a lack of suitable offices, which could adversely affect the public image of the services provided by labour administration bodies given the need for direct contact with the public in many cases (ILO, 1989: 22-4).

In most countries, governments continued to understand the importance of involving employers and workers' organizations in their activities, including the elaboration and implementation of labour policy via bipartite or tripartite advisory bodies (ILO, 1989: 37-8). However, governments, often inspired by economic liberalism and the ideology of New Public Management, reformed labour policies and labour administration services in a number of industri- 
alized countries. In the United Kingdom, deindustrialization contributed to a weakening of trade unions while Conservative governments sought to curtail public expenditure and 'flexibilize' the labour market by repealing or amending labour laws and reducing employment protection. The United States of America also followed a policy of deregulation after 1981 and labour administration was negatively affected by significant staff and budget reductions (ILO, 1989: 25-6). In the Federal Republic of Germany, the initial response to unemployment was to adjust existing policy instruments and create new instruments, such as a pre-retirement benefit scheme (1984) and a scheme to provide financial assistance to unemployed persons to start their own businesses (1986). In Belgium, there was a clear change in the nature of the labour administration's role in collective negotiation, with a shift from a neutral stance to compelling the parties to arrive at agreements that respected government policies to control inflation and also imposing limits to wage increases. In many developing countries there was a parallel movement towards the deregulation of the economy, including the labour market, often in response to the direct advice of the International Monetary Fund, or in response to the burdens of debt payments frequently combined with budgetary austerity measures (ILO, 1989: 26-7). Nevertheless, in Latin America, after a period of military dictatorships, renewed activity by the trade union movement gave rise to an intensification of collective bargaining and conflicts, which denoted the need for a labour administration able to deal with the new situation.

Also during the 1980s, concern over the financial aspects of social security grew in parallel with the growth of the ageing population. Most of the debate was focused on the question of underfunded pensions associated with pay-as-you-go systems and led to attempts to reduce State spending by reforming multi-tiered pension systems as well as efforts to increase the labour force participation of women, thereby reducing the relevance of general provisions for widows' pensions.

\subsection{THE $1990 \mathrm{~S}$}

In several European countries, such as Belgium and Spain, the social partners had been involved in consultation and negotiations concerning social and economic issues for many years. During the 1990s, social dialogue on wider issues emerged in many other countries as a means of coping with economic crises, structural changes in the economy, as well as regional integration. In Central and Eastern Europe, social dialogue developed in the context of economic and political transitions with profound impacts on unemployment and living standards (Roaf et al., 2014). These countries adopted new legislation and started the transformation of their labour markets and labour administrations, using, in most cases, Western European models. The radical liberalization of 
the economic model and its regulation had immediate negative impacts on living standards. In moving from a system of guaranteed employment to labour markets governed by supply and demand, and with the closure of unviable firms and industries, unemployment increased sharply at the start of transition (Roaf et al., 2014: 6). Introducing social dialogue, especially at national level, was seen as a way to avoid social conflicts and reach some consensus on macroeconomic policies, as proved possible for example in the Czech Republic, Hungary, Poland and Slovakia.

Many developing countries created tripartite consultative bodies attached to the Ministry of Labour, dealing with issues such as labour law/regulatory reform, working conditions and policy matters related to labour relations. Examples of such institutions can be found in many parts of the world (Colombia, Costa Rica, Dominican Republic, South Africa, Senegal, Benin, Zambia). Gender equality was also the object of social dialogue-specific institutions, such as the Tripartite Commissions for Equality in Employment established in Argentina, Chile, Paraguay and Uruguay during the period 1995-98 (Ishikawa, 2003: 5, 16, 20). Furthermore, in all of the countries in the Southern Cone of Latin America, an abstentionist role for the State in labour relations was emphasized, giving rise to greater collective autonomy (Oficina Internacional del Trabajo (OIT), 1995).

In Africa and Asia, processes of democratization and efforts to support structural adjustment policies led to broader responsibilities being devolved to Ministries of Labour. The ILO collaborated with a number of governments to help them strengthen their labour ministries (ILO, 1992). In South Africa, with the dismantling of apartheid, a number of institutions were created and transformed under the Reconstruction and Development Program (RDP) since 1993, including the reorientation of programmes and the organization of the Ministry of Labour, and the creation of the National Economic Development and Labour Council (NEDLAC). In China, one of the milestones of labour administration development was the adoption of the Labour Law of 1994, which provided a legal framework for governing the labour market of the socialist market economy. In 1998, the Ministry of Labour changed its name to the Ministry of Labour and Social Security - MOLSS. ${ }^{3}$

During this period, important progress was made in the development of labour inspection services in a number of countries in Latin America (such as Brazil, Chile, Costa Rica, Dominican Republic and Panama), based on recommendations and assistance made by the ILO, providing them with a regulatory framework, competencies, structures and methods that, with increased means provided by their governments, allowed for greater effectiveness. Numerous reform initiatives were also undertaken by Public Employment Services (PES), aimed at improving operational efficiency and service quality, particularly in developed countries. 'In a climate of economic liberalism and globalization, 
the ILO abandoned the notion of the PES monopoly and recognized that Private Employment Agencies (PREAs), with appropriate regulation, could contribute positively to the functioning of the labour market' (Phan et al., 2001: xv). Three important trends affected the organization of the PES: decentralization of authority and responsibility; integration of services; and competitive service delivery (Phan et al., 2001: xix). Organizational reforms were in many cases accompanied by the adoption of new management methods and tools such as strategic and operational planning, performance management or evaluation of programmes. The Organisation for Economic Co-operation and Development (OECD), considering that employment issues were at the centre of current policy debates, conducted studies in developed countries examining the public employment service, with the objective of analysing how best to design and implement efficient and equitable employment-oriented labour market and social policies. Based on those studies, the OECD organized in 2000 an international conference, signalling as directions for the future, the 'increased importance of assisting problem groups and mobilising new labour resources or helping in their adjustment to changing market needs' (OECD, 2001: 31-2).

In 1999, a document prepared by the ILO, entitled: New trends in prevention and resolution of labour disputes (ILO, 1999), showed that the principal methods of dispute settlement in many countries remained conciliation, mediation, arbitration and adjudication established on a statutory basis, and mainly provided by government services or involving an independent and impartial third party. A new development was the entry of alternative dispute resolution (ADR), characterized by the 'privatization' of these services or providing parties with the option of accessing privately provided services. The regulation of strikes in essential services also became a trend in some countries where the right to strike and lock out had traditionally been recognized.

Throughout the 1990s, discussions relating to social security focused on retirement policy and the financial viability of pension schemes in the face of population ageing (Gillion, 2000: 22-3). Some of the Central and Eastern European and Central Asian countries transitioning to a market-based economy adopted defined contribution schemes (Gillion, 2000: 22-3) while a 'number of developing countries were moving from pay-as-you-go (PAYG) to fully funded (FF) individual savings accounts [or from] provident schemes providing lump-sum payments at retirement to a social security scheme that provides benefits periodically' (van Ginneken, 2003: 33-4). In a majority of countries across all regions, the reform, development, adjustment, improvement or modification of pension schemes was an item on the political agenda.

In the context of regional economic integration groups, questions relating to labour administration had begun to be the subject of specialized agreements on social matters. This was the case for example of the North American Free Trade Agreement (NAFTA), the Southern Common Market (MERCOSUR), 
the Andean Group, and the European Union (EU). Aimed at contributing to the creation of a common European labour market, the European Employment Services (EURES) was established in 1993, as a cooperation network of the European Commission and the public employment services of EU countries. A Senior Labour Inspectors' Committee (SLIC) was also established in 1995 to give its opinion on problems relating to the enforcement of Community law on health and safety at work.

\subsection{THE TWENTY-FIRST CENTURY}

At the beginning of the century, policies relating to active labour market policies, fundamental workers' rights, social protection and good governance were considered as being particularly important. The link between trade liberalization and employment was also a key policy issue. ${ }^{4}$ The administration of employment issues in industrialized and some middle-income countries underwent significant changes as governments sought greater coherence between active and passive labour market policies and to delegate more responsibility to local institutional levels (ILO, 2011a: 50; Heyes and Rychly, 2013). Furthermore, '[S]ome governments, considering that it was necessary to achieve a synergy of economic and employment policy, merged the ministry of labour with the ministry of economy or finance, but not without controversies' (Rychly, 2013: 16). In 2002 competence for labour market policy and labour law was assigned in Germany to the Ministry of Economics (since 1957 in the Federal Ministry of Labour and Social Affairs) and the remaining tasks ware assigned to the Ministry of Health and Social Security. In 2005 the original responsibilities of the Ministry of Labour were reconsolidated in a Ministry of Labour and Social Affairs. In the United States of America, the Employment Standards Administration (ESA) was abolished in 2009 and its four major programmes became stand-alone programmes reporting directly to the Secretary of Labor. Other Offices were eliminated, and their administrative functions transferred. ${ }^{5}$ Some countries have taken steps to improve the overall governance and consistency of active labour market policies. In France, the PES was reorganized in 2008 with the creation of a new public institution, Pôle emploi, which saw the merger of the National Employment Agency (ANPE) and the Associations for Employment in Industry and Commerce (ASSEDIC). In Italy, the Jobs Act established a new national agency for an active labour market (ANPAL) to coordinate a wide network of institutions and agencies (European Commission, 2017: 70). In general, the PES has been given a more prominent role, not only in the delivery of placement services, but also in developing and testing programmes to address specific groups of unemployed, such as long-term unemployed or young workers. Nevertheless, the PES in 
developing countries has not progressed significantly and efforts should be focused on building a modern PES and addressing capacity gaps. ${ }^{6}$

In some European countries the administration of employment services has developed into partnerships with local authorities, as in the case of Germany (2004) and also in Norway (between 2005 and 2011). In 2009, Danish municipalities assumed full responsibility for this policy area, under central government regulation and supervision (Lægreid and Rubecksen, 2014). A number of countries have also outsourced employment services for the long-term unemployed (LTU). This is the case in Malta, where a Work Programme Initiative outsourcing profiling, training and job placements for LTU clients aged 25-56 years was introduced. Latvia launched in 2015 a national programme that involved non-governmental organizations (NGOs) as service providers for individual and group consultations, career consultations, health checks, guidance, motivational programmes and addiction treatment programmes (European Commission, 2017: 60).

ICT has enabled labour administration bodies to engage with citizens in new ways. ICT-related reforms have been widespread in recent years and have affected management processes, working practices and service delivery. Research has demonstrated that the use of ICT in labour administration systems is increasing.

ICT has made possible the construction of complex databases, enhanced internal relations between officials across different levels of labour administration, facilitating easier collections and transfers of data, documents, reports and the provision of information to employees. There has been a widespread introduction of websites, email and social media use, and the uptake of software-enabled tablets in labour inspection. Significant challenges remain in developing countries, which experience a general lack of technological connectivity and a widespread lack of technological literacy. (Hastings and Heyes, 2016: 43-4)

In developed countries, the Internet has taken on an increasingly prominent position as a channel as part of an integrated service delivery strategy. The tendency towards more ICT-driven processes is the most-mentioned innovation in both developed and developing countries (OECD/IDB/WAPES, 2016). However, while online channels are increasingly the main service channels in Asia and Europe, in Africa, the Americas and the Middle East/North Africa, the face-to-face channel remains the most prominent one.

In the field of Labour Inspection, some systems formerly organized around safety and health have evolved into a more comprehensive model that, first, integrates safety and health with environmental aspects and, secondly (as a result of recent legislation), also combats illegal employment (in Denmark, Norway, Sweden and the Netherlands). Another integration trend has been to bring together labour inspection services relating to safety and health and 
social insurance under one single system, thereby making it possible to achieve considerable improvements in prevention policy with regard to occupational hazards, as well as significant savings as a result of the more rational use of available resources.

A General Survey published by the ILO in 2006 highlighted that most national legislation empowered labour inspectors to enforce the application of legal provisions pertaining to areas not actually covered by the instruments under consideration, or even entrusted those labour inspectors with certain other functions, such as the settlement of collective labour disputes in a number of African countries and most Latin American countries. As Auvergnon et al. (2011) have reported: 'In French-speaking countries of sub-Saharan Africa, the boundary between labour inspection and labour administration tends to become blurred, as labour inspectors there effectively perform many of the essential functions of labour administration, within the framework of a broad, "general practice" approach to inspection.' However, the labour administration systems of most of the countries continue to suffer from a lack of the financial and human resources and in many developing countries, as well as certain industrialized countries, the resources allocated to labour inspection have been insufficient to enable inspection functions to be discharged properly, resulting in the impact of the labour inspectorate being limited.

Since the last decade of the twentieth century and notably during the first years of the new century, bilateral and regional trade agreements have been adopted in all regions of the world. A number of these trade agreements contain labour provisions, many of which are related to compliance with international and national labour standards, affect national labour administrations and have induced changes in ministries' policies and practices, particularly in relation to labour inspection (ILO, 2013). Labour provisions tend to be concentrated in North-South trade agreements, but there is an increasing trend to integrate labour provisions also into South-South trade agreements (ILO, 2013). Furthermore, the management of labour migration has become an increasingly important issue for labour administration and ministries of labour have participated in the establishment of migration policies with ministries of foreign affairs and interior. ${ }^{7}$ Almost all Western European countries have become recipient countries and they have strengthened policies and structures to manage the increased flows of migrants from Eastern Europe and the other regions. Australia, Canada and the United States of America, among others, are in the same circumstances. In Spain, for example, the Ministry of Labour and Social Affairs was transformed in 2008 into the Ministry of Labour and Immigration, showing the enhanced interest of the politicians in the phenomenon of immigration. As regards developing countries, some of the main sending countries have established units within the ministries of labour to control and assist recruitment and migration. It is reflected in the title of the ministry, as in 
Egypt (Ministry of Manpower and Migration) and Tunisia (Ministry of Social Affairs, Solidarity and Tunisians Abroad) in Africa. Examples in Asia include Indonesia (Ministry of Manpower and Transmigration), Pakistan (Ministry of Labour, Manpower and Overseas Pakistanis) and Sri Lanka (Ministry of Labour Relations and Foreign Employment).

Bilateral labour migration agreements have seen a revival since the 1990s, with a peak observed between 2005 and 2009. Interest was especially evident in certain migration corridors (such as Asia and Africa to the Arab States, and within Asia). Regional economic communities and regional cooperation bodies across the world have adopted a variety of labour migration governance models that range from free movement (the EU model, the Economic Community of West African States - ECOWAS or the Southern Common Market - MERCOSUR), facilitation of movement for specific categories of workers (ASEAN, Caribbean Community - CARICOM, SADC), mere visa reciprocity agreements or regular exchanges of information (Arab Maghreb Union - AMU), or protection of the subregion's workers in destination countries outside the region (South Asian Association for Regional Cooperation - SAARC) (Baruah and Cholewinski, 2006).

Collective bargaining, while still important in many countries of the world, has nonetheless seen a decline in its regulatory role. With this decline arose substantial gaps in the regulation of many workplaces, giving rise to alternative employment practices, including non-standard employment (NSE). NSE includes temporary employment, part-time work, temporary agency work and other multi-party employment relationships, disguised employment relationships and dependent self-employment. The growth of NSE reflects changes in the world of work brought about by globalization and social change but also regulatory changes (ILO, 2016). At times, laws have encouraged the use of NSE - purposefully or unwittingly - by creating incentives for its use by enterprises. In other cases, there are gaps or grey areas in the law that have provided fertile ground for the development of non-standard work arrangements. Some of these gaps have resulted from the decline of collective bargaining in countries where collective agreements had previously been the dominant form of regulation. However, recent policy reforms in many countries have been introduced bringing a larger number of NSE categories within the scope of social insurance coverage. Extending the coverage of schemes to non-covered or insufficiently covered groups and addressing compliance gaps and transaction barriers have been important objectives for all social security administrations in Africa, for example. The extensive use of ICT solutions together with clear and strong contribution collection strategies has permitted progress in compliance and coverage extension (International Social Security Association (ISSA), 2014). The use of Big Data in developed and medium-income countries is another success story for social security administrations. Big Data and 
analytics technologies are being used, for instance, in France, Italy (National Employment Accident Insurance Institute - INAIL), Spain (Tesorería General de la Seguridad Social - TGSS) and Uruguay (Banco de Previsión Social BPS) for detecting evasion and fraud in social security contributions. These institutions are applying predictive analysis using contribution collection as well as benefits-related databases in order to enlarge the available information base (ISSA, 2016).

\subsection{THE POST-CRISIS ERA}

The effects of the 2008 financial and economic crisis on employment and living standards in many parts of the world have highlighted the importance of ministries of labour and other components of national labour administration systems. ${ }^{8}$ Given that labour policy measures were only some of the components within larger recovery packages, the leading role in the coordination of anti-crisis policies remained with ministries of economy or finance in most countries. Nonetheless, labour ministries played a key role when it came to informing government policies, implementing job-creation and job-protection measures, enlarging social protection, strengthening and adapting the delivery of labour administration services (at the time of writing, they are playing a similar role in managing the social consequences of the COVID-19 crisis).

Within this context, various innovative labour policies were developed and applied on a large scale. Those designed to safeguard existing jobs or to better protect vulnerable categories of workers, most often with ministries of labour playing an active role, helped maintain social peace by seeking consensual solutions to mitigate the impact of the crisis (ILO, 2011a). Following the start of the crisis, labour administrations adopted policy measures relating to employment policy, social protection (in some cases extending protection to vulnerable groups), incomes policy and institutional capacities (Rychly, 2009: 3). Most of the policies applied in developed economies and EU Member States, in particular, aimed at decreasing labour regulation (Rychly, 2009: 12-13).

In most countries, the crisis placed the institutional capacity of the PES under severe scrutiny. Some countries responded by increasing the number of PES staff, but in many cases the PES tried to build stronger public-private partnerships. Some countries emphasized individualized service programmes and developed specific programmes or services to target vulnerable groups, such as young or older workers, disabled workers, migrants or long-term unemployed (Rychly, 2009: 12-13). The activities and challenges confronting labour inspection bodies were also affected in a number of ways by the crisis. The crisis seems to have exacerbated the diversity and fragmentation of the employment relationship (temporary work, contract work, part-time work 
and self-employment), undeclared or illegal work and migrant employment, large-scale restructuring and redundancies. With some rare exceptions, governments have not increased the financial and human resources available to labour inspectorates (Rychly, 2009: 14); indeed, they have in some cases been cut. However, 'this situation was not unprecedented: previous crises were typically followed by long periods of fiscal austerity that limited public expenditure, including mandatory social spending, leading to the partial dismantlement of welfare legislation in an effort to reduce budgetary deficits' (Rychly, 2009: 2).

All over the world, ministries continue to change structures and reorganize functions:

- In Colombia, the division of the Ministry of Social Protection into the Ministry of Labour and the Ministry of Health and Social Protection, which had been demanded for years by the union movement, sought to ensure greater compliance with policies for the generation of employment and formalization of labour and compliance with fundamental labour rights, strengthening the labour inspection system. ${ }^{9}$

- In Paraguay, a Law of 2013 created the Ministry of Labour, Employment and Social Security (MTESS), separating it from the Ministry of Justice and Labour. The creation of a separate ministry was intended to overcome the institutional weakness that had characterized for decades the country's labour administration.

- In France, the reform of labour inspection, which mainly developed between 2006 and 2010, was finalized by the creation of a central intervention body, an internal reorganization at different territorial levels (2014) and the creation of an administrative penalty procedure for breaches of certain provisions of the Labour Code.

- The Republic of Georgia re-established in 2014 the Labour Inspection service that had been supressed in 2006. ${ }^{10}$

- In Spain, Labour and Social Security Inspection was also reorganized in 2016, becoming an autonomous body in 2018 .

- In Ireland, the Workplace Relations Act 2015, which commenced on 1 October 2015, provided for two independent bodies (the Workplace Relations Commission and an expanded Labour Court) instead of the five previously in existence. Another Act of 15 July 2015, amending the National Minimum Wage Act 2000, established the Low Pay Commission to make recommendations regarding the national minimum hourly rate of pay.

- In the Netherlands (2012), the Ministry of Social Affairs and Employment merged the three existent inspections into a new inspectorate, the Social Affairs and Employment Inspectorate (SZW Inspectorate). It covers labour 
market fraud, working conditions, major hazard control and has a special department that investigates fraud and other serious offences within the work and income chain, including some social insurance aspects. ${ }^{11}$

- A general statutory minimum wage went into effect in Germany on 1 January 2015. The competent authority for verifying compliance and for sanctioning any violations of the minimum wage legislation is the Customs FKS Financial Monitoring Unit to Control Unreported or Illicit Employment. ${ }^{12}$

Other European Union Member States have also taken further action to tackle undeclared work, in particular by strengthening labour inspections. In September 2015, Italy rationalized the system of labour inspections through the creation of a national inspectorate incorporating three previously distinct institutions, changing the way inspections work. In 2016, Malta established more stringent financial penalties imposed on irregular employment and reinforced the capacity of the labour inspectorate (Law Compliance Unit) within the public employment service (European Commission, 2018: 72).

Social dialogue has also advanced in many countries. A number of countries in Africa recently undertook to create a framework for tripartite social dialogue and policy 'concertation', or to upgrade existing frameworks as a means to enhance participatory governance and consolidate social peace. This was the case in countries such as Senegal, in 2014; in Burundi, in 2013; in Seychelles, in 2013; and in Malawi, in 2015. Other countries undertook to amend their legislation in order to strengthen collective bargaining, such as Rwanda, in 2015. To date, mechanisms for national social dialogue, including economic and social councils, have been set up in some 38 African countries (ILO, 2015).

In the EU, all Member States have bipartite or tripartite bodies to allow for the interaction of social partners and for their consultation in the design and implementation of policies. Their actual involvement, however, varies significantly in line with national practices and conditions. At the start of the global crisis in 2008, governments and social partners in some European countries with well-developed social dialogue and collective bargaining mechanisms adopted agreements in search of solutions to reduce the impact of the crisis on wages and employment. However, as the crisis deepened, in countries like Belgium, Bulgaria, Hungary, Poland and Romania the role of social dialogue institutions was diminished, social partners were not consulted on important measures and reforms, or tripartite agreements were not always respected (Papadakis and Ghellab, 2014: 2, 16). Nevertheless, a few EU Member States, for example, France, Lithuania and Romania, took action in 2015 and 2016 to strengthen social dialogue and improve the involvement of social partners in employment and social policies (European Commission, 2018: 4, 74, 77). 


\subsection{CONCLUSIONS}

Forty years after the adoption of ILO labour administration international instruments, there is a general consensus among countries that labour administration and labour inspection are institutions for good governance and are essential to achieve the decent work objectives, to promote compliance with and enforcement of labour legislation and to protect workers' rights. ${ }^{13}$ Furthermore, the financial crisis has contributed to a review of some of the assumptions that have informed economic policy over the past 30 years, prompting a reconsideration of these approaches, particularly as they relate to international financial institutions. For example, the International Monetary Fund (IMF) recognized that social protection policies play a major role in cushioning populations from economic shocks and in improving social cohesion. In particular, the positive role of unemployment benefits as an automatic stabilizer has been underscored (ILO, 2011a).

When ILO Convention No. 150 and Recommendation No. 158 were discussed and adopted (1978), the vision of the world of work and of the role of labour administration of labour was influenced by the circumstances prevailing in those times. Those circumstances have been progressively changing and labour administrations in general, and employment services and labour inspection in particular, have had to adapt.

Changes in the conception and formation of the State, for example the restoration of democracy and transition to a market economy (USSR, Central and Eastern European countries) and accession to supranational organizations (like the EU), have produced multiple effects on labour administration. In developing countries, the structural adjustments driven by the international financial institutions with austerity measures, 'adjustment plans' and declining real incomes resulted in a contraction of the public sector as a whole. However, labour administration, being seen as low priority and already underfinanced, suffered more than other areas of public administration in terms of budget and staff cuts.

Economic circumstances have also had an impact on labour administration. ${ }^{14}$ The continuing internationalization of the world's production systems, with increasingly complex global supply chains, has presented challenges to labour administration, particularly in relation to inspection and enforcement while the erosion of national labour market institutions in some countries has contribute to growing income inequality. In addition, economic crises have been compounded by natural disasters, wars and internal conflicts. Several African countries switched to more democratic systems ${ }^{15}$ and some saw the end of long civil wars. ${ }^{16}$ Mergers, separations and reductions in labour administration services occurred in times of contraction in spending. On the other 
hand, in times of expansion, new functions were developed, new bodies were set up, and recruitment of personnel and investment in technologies tended to follow.

The industrial relations system and the role of social partners have evolved with the times, requiring the response and adaptations of labour administrations to the nature and character of industrial conflicts, mainly through the creation of mediation services administered by social partners and procedures established by collective agreements. Even though collective bargaining in some countries has become more widespread and its scope extended, the regulation of working conditions, in general, is far from becoming autonomous and the government's regulatory function has not only been maintained, but also in many cases increased. Social dialogue, either tripartite or bipartite, has contributed to the solution of many problems. The involvement of employers' and workers' organizations in the governance of the labour market and social security system has led to their participation in advisory councils and governing bodies in a number of agencies and institutes.

Reforms in public administration systems have involved the adoption of new management practices and organizational forms in labour administration and a reconsideration of the boundaries between the public and private sectors. The structure and internal organization of a labour ministry is itself a reflection of its mandate and policy implementation model. A majority of labour ministries have assumed competences in the areas of work (labour relations, conciliation, working conditions, occupational safety and health), employment (PES, employment programmes and vocational training), social security benefits and labour migrations. Transformations are observed in each of these areas in various ways. The unitary vertical organization of labour administration, which is still maintained in some countries (although rarely in a pure state), has largely given way to more horizontal systems, based on specialization and decentralization, with a profusion of many autonomous bodies and institutes. ${ }^{17}$ Furthermore, the use of new technologies has affected management processes, working practices and service delivery, creating new methods of relation between citizens and labour administration. Performance management practices have been central to many governments' attempts to improve coordination (Heyes, 2011) and the incorporation of new technologies and new methods and procedures has helped to improve efficiency, especially in employment services and in the management of social security contributions and benefits.

The key challenges relating to the capacity of labour administration at this time, especially in developing countries, are the weakening mandate of labour ministries, management inadequacies, lack of coordination capacity, insufficient budget allocations and equipment, inadequate human resources policy, and weak capacity to enforce labour laws. The use of new technologies is facil- 
itating information flows across different levels of hierarchy, departments and services and changing the methods of interaction with citizens. Nevertheless, a digital divide persists between developed and developing countries (ILO, 2011a: 54; Galazka, 2015). Modernization efforts, already applied in industrialized countries, are not easily replicable in other countries without strong political decisions, training and investments (ILO, 2011a: 55).

There are also key challenges that relate to the regulation of the labour market and protection of workers. Of great importance is the extension of labour administration services to all categories of workers. The scope of application of labour standards usually covers all situations in an employment relationship, where there is an employer and an employee. Nevertheless, in many developing countries some categories of employers and workers are excluded from those scopes of application. Governments should then focus more on the regulatory frameworks. This is a challenge because legislating rights for workers meant imposing obligations on employers (Daza, 2008: 223-4). On the other hand, the extension of social security coverage to those that are not in an employment relationship, like independent or self-employed workers, implies the payment of contributions by themselves. This issue is linked to that of the informal economy. The differing visions of the phenomenon of informality around the world determine different attitudes on the part of the public authorities. Still, the informal economy continues to be dominant in many developing countries. Treating informal activities as a means of subsistence and considering the inadequacy of regulation of large segments of the labour market has led to tolerance or ignorance on the one hand and political proposals to procure or facilitate some degree of protection on the other. Generally, efforts to enforce existing legislation in developing countries have been scant, since governments have been overwhelmed by the growth of informality and have not seen the need to adopt firm or repressive measures. On the other hand, in industrialized countries, where informality is regarded as a breach of the rules of the market, related to fraud and illegal work, the attitude of public administrations has tended to promote compliance with standards by all possible means and to strengthen labour inspection systems (Daza, 2005: 16).

Finally, it should be emphasized that strong and efficient labour administration is crucial for ensuring Fundamental principles and rights at work $(F P R W)$. However, in some of the areas where the worst violations of FPRW occur, labour administration is largely absent. In most countries, the role of labour administration in freedom of association and collective bargaining is concentrated on assistance and settlement of disputes, as violations of those rights are usually submitted to labour courts. Labour inspection mandates refer mostly to violations of rights covered by labour legislation, with restricted capacity to tackle some instances of forced labour. A number of countries are giving new attention to forced labour practices, child labour and discrimina- 
tion, including the establishment of special units, but in many others it remains a challenge (ILO, 2017: 62).

\section{NOTES}

1. An exception is Gavris and Heyes (2019).

2. This article contains a detailed description of the evolution of labour administrations since the nineteenth century to the first half of the twentieth century.

3. For a detailed description of labour administration system in China, see Casale and Zhu (2013).

4. In March 2002, a Working Party organized by the ILO examined the issue of trade liberalization and employment. A discussion paper prepared by the ILO reviewed recent theoretical and empirical work on the links between trade liberalization and employment and highlighted key policy issues.

5. DOL USA. https://www.dol.gov/whd/about/history/whdhistReorg.htm (accessed 31 May 2017).

6. Convention 143 - Migrant Workers (Supplementary Provisions) Convention, 1975 (No. 143) Convention concerning Migrations in Abusive Conditions and the Promotion of Equality of Opportunity and Treatment of Migrant Workers.

7. See as a reference ILO (2010).

8. The European debt crisis, in the banking system of the European countries using the Euro, followed later, since the end of 2009.

9. Reformas de la administración pública. Ley 1444 de 2011. Facultades Extraordinarias.

10. In 2006, when the Republic of Georgia enacted a new Labour Code, the labour inspectorate was abolished. Thereafter, no authority was responsible for the supervision of labour legislation. In 2015, a Government Decree on approving the statute of the Ministry of Labour, Health and Social Affairs created the Department for the Inspection of Labour Conditions.

11. From 2011, 2012 and 2015 Annual Reports of the Social Affairs and Employment Inspectorate (SZW Inspectorate) Summary.

12. Minimum Wage Act of 11 August 2014 (Federal Law Gazette [BGB1.] Part I, p. 1348), as amended by Article 2 of the Act of 17 February 2016 (Federal Law Gazette I (p. 203).

13. ILC Resolution and Conclusions on labour administration and labour inspection. 2011.

14. In 2011, the Director-General of the ILO, addressing the ILC stated, 'Since 1980, on average a financial crisis has rocked the world every three years' (ILO, 2011b).

15. Benin 1998-91; Burkina Faso 1991; end of apartheid in South Africa 1993.

16. Angola 2002-08; Sierra Leone 2002; Liberia 2005.

17. For detailed information see Rychly (2013).

\section{REFERENCES}

Auvergnon, P., Laviolette, S., and Oumarou, M. (2011), 'Labour administration in sub-Saharan Africa: Functions and challenges in the light of ILO Convention No. 150', International Labour Review, 150, 1-2. 
Baruah, N., and Cholewinski, R. (2006), Handbook on establishing effective labour migration policies in countries of origin and destination, OSCE-IOM-ILO, Geneva.

Casale, G., and Zhu, C. (2013), Labour administration reforms in China, ILO, Geneva.

Daza, J.L. (2005), Informal economy, undeclared work and labour administration, DIALOGUE Paper No. 9, ILO, Geneva.

Daza, J.L. (2008), 'Legal determinants of labour informality', in Berg, J. and Kucera, D. (eds), In defence of labour market institutions: Cultivating justice in the developing world, Palgrave Macmillan and ILO, New York and Geneva.

European Commission (2017), Joint employment report from the Commission and the Council accompanying the Communication from the Commission on the Annual Growth Survey 2017, Social Europe, Brussels.

European Commission (2018), Joint employment report from The Commission and the Council accompanying the Communication from the Commission on the Annual Growth Survey 2018, Social Europe, Brussels.

Galazka, A. (2015), Report on the global survey into the use of information and communication technologies in national labour administration systems, Governance and tripartism working paper, ILO, Geneva.

Gavris, M., and Heyes, J. (2019), 'Varieties of labour administration in Europe and the consequences of the Great Recession', Economic \& Industrial Democracy. doi: $10.1177 / 0143831$ X19861749.

Gillion, C. (2000), The development and reform of social security pensions: The approach of the International Labour Office, ILO Social Security Department, ILO, Geneva.

Hastings, T., and Heyes, J. (2016), Comparative developments in labour administration, ILO, Geneva.

Heyes, J. (2011), Labour ministries and labour administration in transition: Recent developments and future prospects, ILO, Geneva.

Heyes, J., and Rychly, L. (2013), 'Introduction: The origins and development of labour administration', in Heyes, J. and Rychly, L. (eds), Labour administration in uncertain times, Edward Elgar, Cheltenham, UK and Northampton, MA, USA and ILO, Geneva, pp. 1--17.

ILO (1989), Labour administration in a changing world, ILO Labour Administration Branch (drafted by Glen Sheehan) Document No. 15, ILO, Geneva.

ILO (1992), Democratization and the ILO, Seventy-ninth session of the ILC, report of the Director-General (Part I), ILO, Geneva.

ILO (1997), General Survey on the Labour Administration Convention (No. 150) and Recommendation (No. 158), 1978. Report of the Committee of Experts on the Application of Conventions and Recommendations, ILO, Geneva.

ILO (1999), New trends in prevention and resolution of labour disputes GB.274/3 274th Session, Geneva, March 1999. Third item on the agenda. Date, place and agenda of the eighty-ninth session (2001) of the Conference, ILO, Geneva.

ILO (2006), General Survey of the reports concerning the Labour Inspection Conventions and Recommendations, 95th Session of the International Labour Conference, 2006. Report III (Part 1B), ILO, Geneva.

ILO (2010), International labour migration. A rights-based approach, ILO, Geneva.

ILO (2011a), ILC, 100th Session, 2011. Report V. Labour administration and labour inspection. Fifth item on the agenda, ILO, Geneva.

ILO (2011b), Report of the Director-General: A new era of social justice, 100th Session of the International Labour Conference, ILO, Geneva. 
ILO (2013), Social dimensions of free trade agreements, Revised edition 2015, International Institute for Labour Studies, Geneva.

ILO (2015), Towards inclusive and sustainable development in Africa through decent work, Report of the Director-General (thirteenth African Regional Meeting (Addis Ababa, Ethiopia, 30 November-3 December 2015), ILO, Geneva.

ILO (2016), Non-standard employment around the world: Understanding challenges, shaping prospects, ILO, Geneva.

ILO (2017), Fundamental principles and rights at work: From challenges to opportunities, ILC, 106th Session, 2017. Report VI, ILO, Geneva.

Ishikawa, J. (2003), Key features of national social dialogue: A social dialogue resource book, ILO InFocus Programme on Social Dialogue, Labour Law and Labour Administration, ILO, Geneva.

ISSA (International Social Security Association) (2014), Africa: Strategic approaches to improve social security, ISSA, Geneva.

ISSA (International Social Security Association) (2016), Ten global challenges for social security, ISSA, Geneva.

Lægreid, P., and Rubecksen, K. (2014), Administrative reforms and accountability relations in the welfare states comparing health and labour administration in Norway, Denmark and Germany, Working Paper 10 - 2014, Stein Rokkan Centre for Social Studies Uni Research, Bergen.

OECD (2001), Labour market policies and the public employment service: Lessons from recent experience and directions for the future, Proceedings of the Conference held in Prague, Czech Republic, on 3-4 July 2000.

OECD/IDB/WAPES (2016), The world of public employment services: Challenges, capacity and outlook for public employment services in the new world of work, Inter-American Development Bank, Washington, DC.

OIT (1995), Las Relaciones Laborales en el Cono Sur. Estudio Comparado (Labour relations in the Southern Cone. Comparative study), Informe RELASUR, OIT and Ministerio de Trabajo y Seguridad Social, Madrid.

Papadakis, K., and Ghellab, Y. (eds) (2014), The governance of policy reforms in southern Europe and Ireland: Social dialogue actors and institutions in times of crisis, ILO, Geneva.

Phan, T., Hansen, E., and Price, D. (2001), The public employment service in a changing labour market, ILO, Geneva.

Roaf, J., Atoyan, R., Joshi, B., Krogulski K., and an IMF Staff Team (2014), 25 years of transition: Post-communist Europe and the IMF, Regional economic issues special report, International Monetary Fund, Washington, DC.

Rychly, L. (2009), Labour administrations and national labour policies. Current challenges, practices and policies, ILO, Geneva.

Rychly, L., (2013), Ministries of labour: Comparative overview, ILO, Geneva.

Van Ginneken, W. (2003), Extending social security: Policies for developing countries, ESS Paper No. 13, ILO, Geneva.

Wallin, M. (1969), Labour administration: Origins and development, International Labour Review, 100, ILO, Geneva. 